\title{
The Potential of Animal By-Products in Food Systems: Production, Prospects and Challenges
}

\author{
Babatunde O. Alao ${ }^{1, *}$, Andrew B. Falowo ${ }^{1}$, Amanda Chulayo ${ }^{1,2}$ and Voster Muchenje ${ }^{1}$ \\ 1 Department of Livestock and Pasture Science, University of Fort Hare, Private Bag X314, Alice 5700, \\ South Africa; anddele2013@gmail.com (A.B.F.); mhuluwam@gmail.com (A.C.); vmuchenje@ufh.ac.za (V.M.) \\ 2 Dohne Agricultural Development Institute, Department of Rural Development and Agrarian Reform, \\ Private Bag X15, Stutterheim 4935, South Africa \\ * Correspondence: alaoboo@hotmail.com; Tel.: +27-833-46-4435
}

Received: 9 May 2017; Accepted: 16 June 2017; Published: 22 June 2017

\begin{abstract}
The consumption of animal by-products has continued to witness tremendous growth over the last decade. This is due to its potential to combat protein malnutrition and food insecurity in many countries. Shortly after slaughter, animal by-products are separated into edible or inedible parts. The edible part accounts for $55 \%$ of the production while the remaining part is regarded as inedible by-products (IEBPs). These IEBPs can be re-processed into sustainable products for agricultural and industrial uses. The efficient utilization of animal by-products can alleviate the prevailing cost and scarcity of feed materials, which have high competition between animals and humans. This will also aid in reducing environmental pollution in the society. In this regard, proper utilization of animal by-products such as rumen digesta can result in cheaper feed, reduction in competition and lower cost of production. Over the years, the utilization of animal by-products such as rumen digesta as feed in livestock feed has been successfully carried out without any adverse effect on the animals. However, there are emerging gaps that need to be further addressed regarding the food security and sustainability of the products. Therefore, the objective of this review highlights the efficacy and effectiveness of using animal by-products as alternative sources of feed ingredients, and the constraints associated with their production to boost livestock performance in the industry at large.
\end{abstract}

Keywords: animal by-products; environmental pollution; feed; livestock; rumen digesta; utilization; food security; sustainability

\section{Introduction}

Meat and meat products form an important segment of the human diet because they provide essential nutrients which cannot be easily obtained through vegetables and their derived products [1]. They provide a means for reducing malnutrition and increasing household food and food security [2]. Over the last 20 years, the demand for meat and meat products has increased in many parts of the world (including Africa, Asia, Europe and United States of America) and this has led to rapid surge in livestock production for sustainable food security [3]. The process of converting livestock to meat in abattoirs usually generates a lot of by-products which can be further utilized by humans as food or reprocessed as secondary by-products for both agricultural and industrial uses [4]. The yield of these by-products has been reported to account for about $10 \%$ to $15 \%$ of the value of the live animal in developed countries, although animal by-products account for about two-third of the animal after slaughter [5]. Basically, animal by-products include all parts of a live animal that are not part of the dressed carcass such as liver, heart, rumen contents, kidney, blood, fats, spleen and meat trimmings. In this sense, the production of these animal by-products can be grouped into non-carcass meat (EBPs) and non-meat products (IEBPs) as shown in Figure 1. 


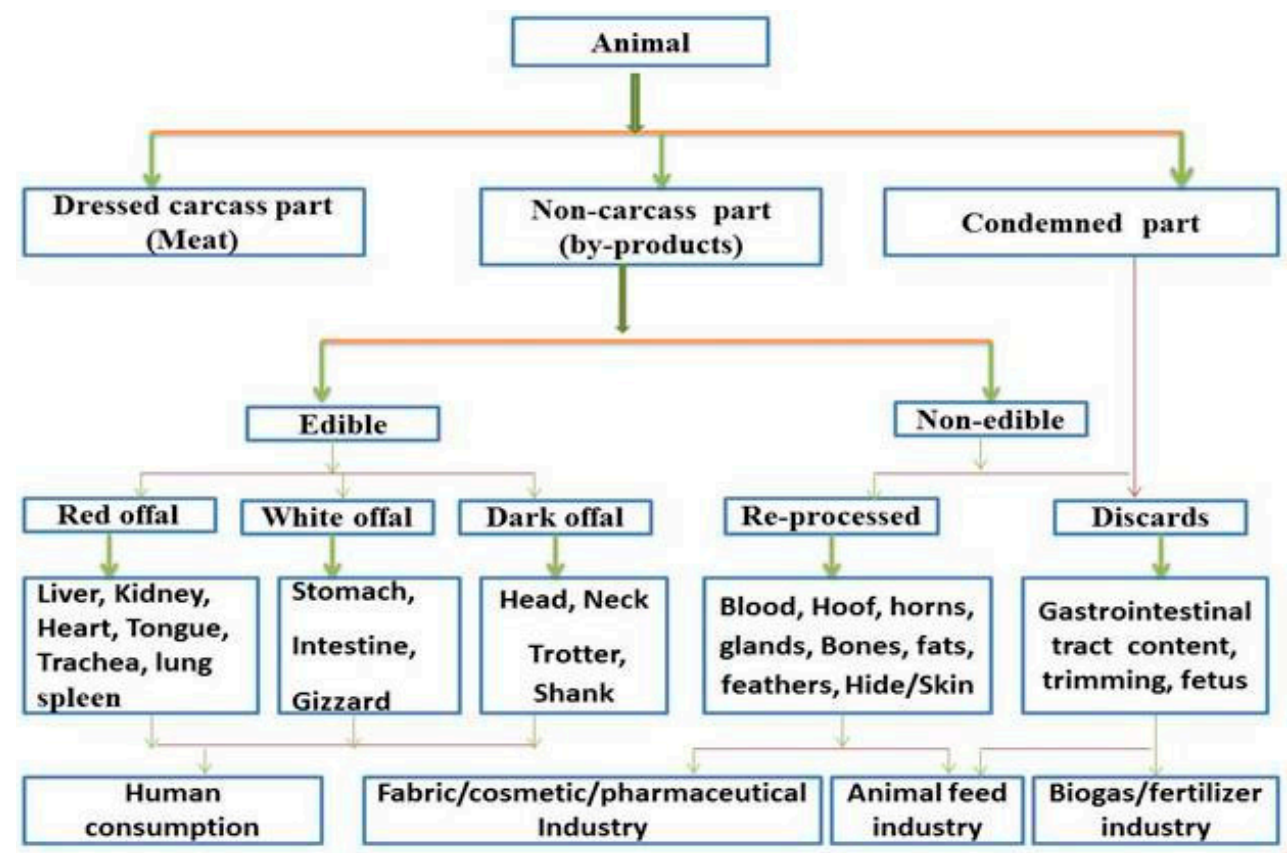

Figure 1. Classification of animal by-products.

EBPs are products that are approved by registered public health inspector and considered safe for human consumption after inspection in the abattoir. In contrast, IEBPs cannot be consumed by humans and are condemned as discards or re-processed and used as secondary by-products. Most EBPs, especially the liver, kidney, tongue and heart, have the potential to provide essential nutrients where meat and meat products are limited or insufficient to meet the nutritional requirements of people [6]. Today, the world is facing a huge problem on food insecurity and climate change, which has resulted to malnutrition especially in the developing countries [7].

Over two billion people in the world, especially in developing countries, have been reported to be suffering from the deficiency of key food nutrients such as vitamins and minerals (including vitamin $\mathrm{A}$, iodine, iron and zinc) [8]. Meeting the nutritional needs of these people will require about $20 \mathrm{~g}$ of animal protein (meat, fish, egg and milk) per person per day or $7.3 \mathrm{~kg}$ per year [8]. Therefore, protein sources such as EBPs could be employed to reduce the menace of malnutrition and food insecurity. It has been proposed that studies involving the use of EBPs as food ingredients should be promoted and evaluated [9]. For this reason, Ockerman and Basu [10] reported that EBPs contain essential nutrients such as vitamins (B1, B2, B6, and folic acid), proteins, minerals and fat, with important poly-unsaturated fatty and amino acids which comparable to those in muscular tissue.

On the other hand, IEBPs such as bones, hides and skin, feathers, hooves, horns, hair, bristles and rumen digesta (Figure 2) can be transformed into useful and valuable products for human and livestock consumption [5]. It is widely accepted that bone can be re-processed into livestock feed (source of minerals) while skin/hide and feathers can be processed and utilized in the upholstery, leather and textile industry. However, the utilisation of rumen digesta could serve as an alternative feed source for the livestock industry since most developing countries are experiencing a shortage of feed ingredients due to extreme climate condition, increase in cost of feed and competition for cereal crops between humans and livestock [11]. Therefore, this review highlights the importance of animal by-products in food system as sources nutrient for humans and alternative feed ingredients for livestock industry. 


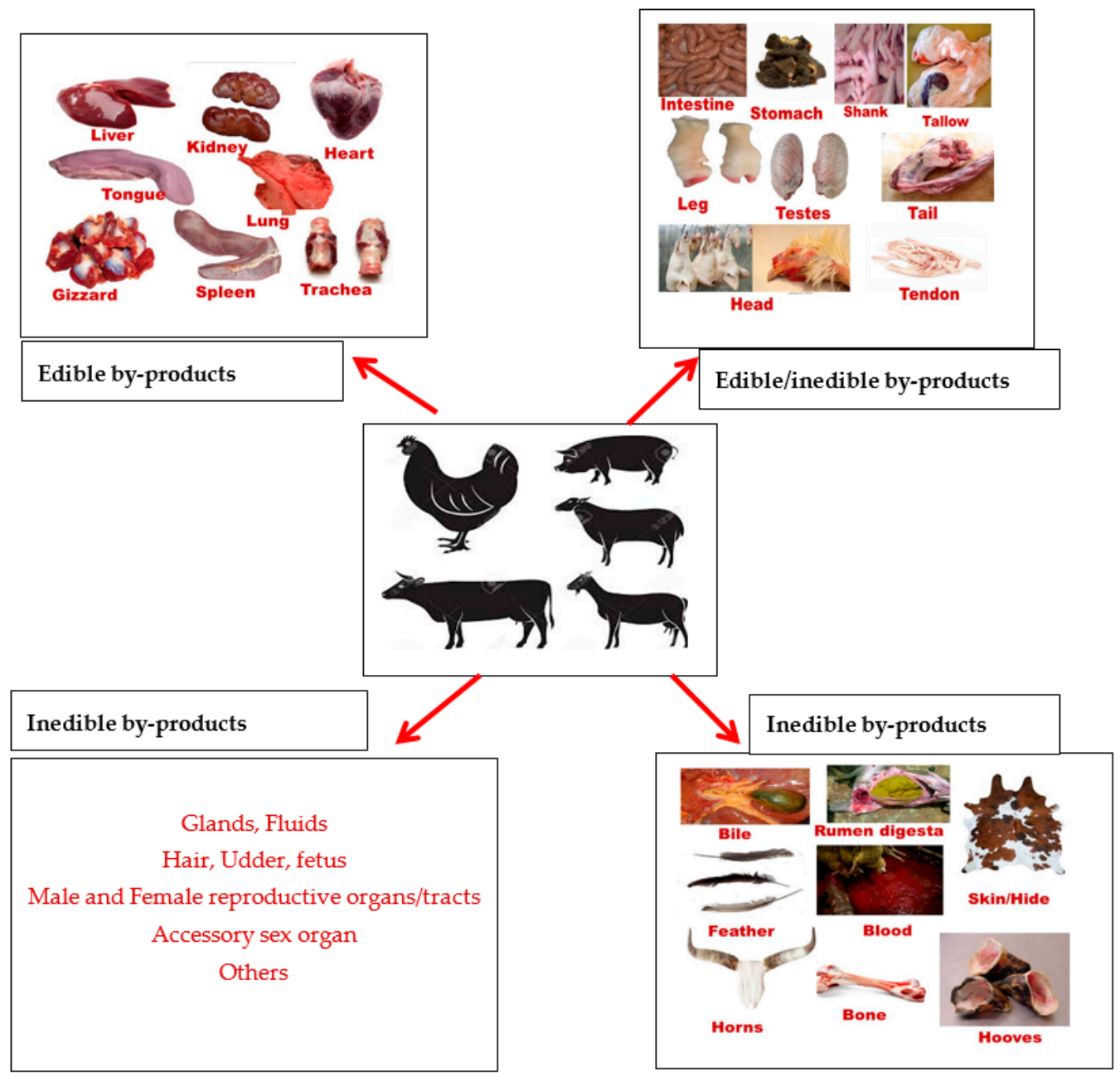

Figure 2. General descriptions of edible and inedible by-products.

\section{Classification of Animal By-Products}

The description and classification of animal by-products differ from country to country and according to different usages in the meat industry. They can be classified as EBPs and IEBPs (Figure 1), or organ and non-organ by-products [12]. They are also sometimes classified based on muscular structure, shape and colour [13]. Regardless of this, the offal can be sub-grouped into white offal, dark offal and red offal [14].

\section{Consumption and Nutritional Composition of Edible By-Products}

Regulations require that EBPs be examined by a public health inspector immediately after slaughter and approved to be free from infections (such as fasciolosis, fibrosis, echinoccosis, tuberculosis, hydatidosis and abscess) and physical abnormalities before processing for human consumption $[15,16]$. If diseases and abnormalities such as bruises are found in any organs and carcasses, the affected parts or whole organs are usually condemned and discarded or declared unsafe for human consumption. Other by-products such as the intestine and stomach are thoroughly washed and heat-treated to remove any dirt and to also destroy any microbes present that might cause infection or pose a health risk to consumers [17]. Products such as tongue are usually graded on surface integrity, colour and defects which include cuts on the membrane, warts and physical abnormalities or diseases [16]. 
The consumption of EBPs across the world is gradually increasing due to the discovery of their importance as a source of nutrients for human benefit. They are widely used in traditional culinary in Europe, South America, North America, Asia, Africa and Australia [17,18]. In Africa, all parts of EBPs are processed and commonly used as human food [18]. In South Africa, EDP delicacies are enjoyed and accepted as one of the traditional norms shared collectively between white South Africans (especially Afrikaners) and black South Africans [19]. A study conducted in Somalia revealed that EBPs are culturally acceptable and consumed by people of all ages [20]. EBPs are usually eaten after frying, grilling, boiling or braising with vegetables and other ingredients. In some cultures, liver meat is processed and consumed in different forms such as liver pâté, foie gras and liver sausages [21-23]. This is due to the richness of animal liver in protein, fat, iron, copper and vitamins which are important for normal development in humans.

In a recent survey conducted among 1030 United Kingdom public members, $43 \%$ of the respondents indicated that they eat chicken livers [24]. The study also revealed that chicken liver dishes are eaten by people of ages ranging from 18 years and above. On the nutritional basis, beef heart and liver have been reported as important dietary sources of Coenzyme Q10 (vitamin) compared to muscle tissue [25]. In addition to this, the digestibility of coenzyme Q10 in beef heart and liver was significantly higher than the digestibility of coenzyme Q10 in muscle tissue. Coenzymes Q10 are produced mainly in mitochondria, which show that liver and heart muscle contain higher mitochondria than other parts of muscle tissue.

It is well known that the liver is a vital edible organ that forms $1-2 \%$ of the live weight of cattle and is richer in minerals and vitamins compared to other muscular tissue [26]. Beef liver was reported to contain about $3.5 \%$ to $7.8 \%$ lipid at wet basis $[27,28]$. In general, lipids from ruminant liver appear to contain more longer-chain polyunsaturated fatty acids (PUFA), stearic acid (18:0) and less palmitic acid (16:0) than the ruminant muscle [28]. The concentration of PUFA in the liver has been reported to be ten times higher than that of muscles from the same animals [28]. Seong et al. [29] also found that the fat content of pork liver was comparable to those of the muscle tissues of cattle. Fats serve as building blocks of membranes and play a key regulatory role in numerous biological functions.

Liver protein contains essential functional features that are associated with different protein portions and with physiochemical conditions such as $\mathrm{pH}$, ionic strength, and high level of water soluble protein [30,31]. However, sheep liver was reported to contain a higher value of di-unsaturated (C18:2) and tri-unsaturated (C18:3) fatty acid than longissimusdorsi muscle [28]. Similarly, there was lower saturated (C16:0, C16:1) fatty acid values in liver compared to longissimus dorsimuscle. Purchas and Busboom [32] reported that beef liver contains relatively higher iron content than beef muscle. Iron is needed for proper functioning of blood in the human system and its deficiency can result in anaemia, especially in pregnant women and children [33]. The liver has also been found to contain a moderate amount of taurine, carnosine, and creatine [32] compared to other muscle tissues.

Heart muscles have been reported to contain a large amount of threonine, leucine, lysine and tryptophan and other amino acids [34]. The proximate composition and amino acid profile of gizzard were reported to be similar to that of chicken meat [35]. Gizzards from poultry can be processed to produce fermented sausage or served fried or eaten with other food ingredients. Chicken gizzard is high in protein $(26 \%)$, ash $(1.3 \%)$ and low in fat $(0.9 \%)$ [36]. Bovine intestine is commonly used as sausages casings $[37,38]$. Blood and viscera organs from goat have been reported to be rich in protein, fat and mineral content (phosphorus and iron) in a measure similar to those of goat muscle tissue [39]. The tongue is also known to provide quality protein, vitamins and minerals which could be beneficial nutritionally [16,40]. It is rich in iron, zinc, choline and vitamin B-12; its utilisation showed that each portion of cooked cow tongue can boost iron content in the body system to provide about $28 \%$ and $12 \%$ of the daily iron intakes set for men and women, respectively [40]. In this sense, beef, pork, sheep, goat and veal tongues can be processed by curing, boiling, smoking and seasoned with onion and other spices before consumption. Cow tongue is consumed as special delicacies in North America, Africa, 
Europe and Asia as a nutritional food source [41]. However, research on textural and organoleptic properties of the cooked cow tongue is still limited.

A study on beef and pork testicles has shown that they are relatively rich in lipid, iron, protein and poly-unsaturated acids [42]. Pork testicles are reported to contain $10.5 \%$ protein, $2.9 \%$ fat and $1.3 \%$ carbohydrate [43]. The concentration of the heme iron in pork testicles $(2 \mathrm{mg} / 100 \mathrm{~g}$, uncooked weight) has been specified to be at least 2.5 times higher than that in pork loin which can provide $25 \%$ of the United States Department of Agriculture (USDA) daily recommended intake for adult males [43]. The testicles and penis from livestock are customarily eaten in many parts of the world as a means to enhance male strength, virility, and prowess [44]. In the United Kingdom and the United States, spleens are broadly consumed in processed foods while, in Sicily, it is used for making the sandwich "pani ca meusa", or "bread with spleen" and caciocavallo cheese [17]. However, consumers may sometimes prefer offal to meat due to availability, nutritional value, price difference, cultural background and religious belief. With the fast growing population, the demand for offal is likely to increase in regards to individual perception. In this regard, further research on consumer perception on consumption of EBPs should be carried out. This will give a comprehensive representation on factors influencing offal demand.

\section{Factors Influencing the Yield and Quality of Edible and Inedible Animal By-Products}

\subsection{Edible By-Products}

The yield and quality of edible animal by-products depend on multiple interactive factors of genotype (breed), sex, animal species, production system (feedlot or pasture-based system), physiological and health condition of the animal, age, weight, post-mortem handling and processing [45]. Florek et al. [45] reported that variation in weight of the by-products is due to differences in animal weight at slaughter, indicating that animal of the same breed and species with high body weight gain will produce more kilogrammes of by-products than those with low body weight.

Florek et al. [45] reported that veal from calves has higher fat, energy, ash, minerals ( $\mathrm{n} n$ and $\mathrm{Ca}$ ), fatty acids and oxidative stability than the liver, tongue, heart and kidney from suckling calves. Hoffman et al. [46] in their study also found a significant breed effect on the proximate composition of all the organs meat, with Merino sheep having higher fat content in liver, and tongue than Dorper sheep. However, Dorper brain, heart, kidney, spleen and testicles had higher protein contents than those of the Merino. It was also found that Dorper liver had higher levels of valine, tyrosine, isoleucine, phenylalanine and leucine than Merino liver. Li et al. [26] reported higher significant differences in the protein, fat, carbohydrate, total energy, mineral, amino acids, polyunsaturated fatty acids and glycogen values of liver meat from Wagyu $\times$ Qinchuan cattle than from Qinchuan cattle raised on the same pasture.

Furthermore, Puschner et al. [47] found that mineral content (copper) of calves varied according to age, sex and production system while the amount of copper in liver was higher in dairy calves than beef calves. In addition, copper concentration in the liver for both dairy and beef calves increased initially for the first 2 months of age and then declined until about 9-10 months of age when concentrations began to increase slightly. Zawacka et al. [48] in their study showed that Capons chicken had higher liver and gizzard weight and lower heart weight than cockerels. In addition, Zawacka et al. [48] has shown that the physiological condition of the animal could influence weight variation, and this is similar to the result obtained by Abdelmageed et al. [49] that the gizzard weight of male broiler chickens was heavier than those from female chickens. On the other hand, buffalo had heavier hearts, lungs, kidney fat and spleens and lighter livers compared to cattle liver, heart and spleen [32]. 


\subsection{Effect of Thermal Processing and Preservation Methods on Quality of Edible By-Products}

It is well known that EBPs are highly perishable and must be stored under refrigerated conditions to control microbiological growth and other deteriorative changes. Shortly after slaughter, the EBPs are washed with clean running water, hung on hooks for cooling and drip drying and then chilled to reach a core temperature less than $7{ }^{\circ} \mathrm{C}$ within $16 \mathrm{~h}$ to prevent any deterioration or spoilage by microorganisms. To a certain degree, EBPs can be chilled at $0-2{ }^{\circ} \mathrm{C}$ for 7 days without negative impact on their quality. However, at frozen temperatures of $-12,-18$ and $-24^{\circ} \mathrm{C}$, liver meat shelf life could be extended to 4, 12 and 18 months, respectively [50]. These preservative mechanisms are employed to ensure that EBPs are safe for consumption by the end-users, although some authors have reported the presence of different microorganisms such as Escherichia coli, Staphylococcus aureus, Clostridium perfringens in EBPs from cattle, pig and sheep [51-53]. Moreover, this has been attributed to poor hygienic quality of the products due to their uncontrolled processing, storage, and handling.

Studies on the impact of packaging on the quality of edible offal during cold storage are still limited. Moreover, it is required that these products are processed, wrapped, boxed and frozen for shipment in order to preserve quality and increase marketability. Traditionally, EBPs are prepared and cooked by boiling, roasting, smoking, frying and microwaving before eaten. Cooking is carried out to destroy microbial contamination and improve the palatability and quality of the products. Among the cooking processes, boiling seems to be the most common practice with all different recipes. Contaminants such as Campylobacter have been implicated on both the inside tissues and the outer surfaces of fresh liver meat, especially in poultry and lamb liver [24]. To ensure that meat and other EBPs are safe for eating, an appropriate cooking temperature is needed to reduce the risk of food-borne infection. Destruction of cyst in meat could be achieved when the internal temperature of the meat reaches a temperature of $67^{\circ} \mathrm{C}$ but uneven heating from microwave may not destroy the parasites completely [54]. Recent work on cooked liver revealed that application of heat at 60 and $80^{\circ} \mathrm{C}$ did not significantly affect the fatty acid and mineral composition of the liver meat from cattle raised on pasture-based diets [55]. Apart from this report, no other scientific studies seem to be available on the effect of heat treatment on quality of EBPs.

\section{Utilization of Inedible By-Products}

IEBPs as stated earlier represent discards that are unsuitable for human consumption and rejected as wastes (blood and stomach contents) or reprocessed into secondary products (gelatine and keratin extraction, belts, footwear, and pharmaceuticals) as shown in Figure 1. Most inedible animal by-products consist of hides, hair, horns, teeth, blood, fats, bone, ligaments and cartilage, feet, manure, trimmings, rumen contents and glands (Figure 2). IEBPs can be further separated into parts such as elementary and secondary by-products [56]. Elementary by-products are by-products which are described as being collected after slaughter and include blood, bones, pancreas, intestine, hides and skins, hoofs and horns (Figure 2). Secondary by-products are by-products which are obtained as derivatives from elementary by-products; this may include products like, buttons, bone meal, insulin, cutlery handles, tennis strips, fat and gelatine. Hides from abattoir are often exported to different parts of the world such as South America, Asia, North America and Europe for reprocessing, and later converted to leather through the use of tanning agents for the production of secondary by-products like shoes, clothing, car seats, and many other items [57]. Other IEBPs such as glands are vital to the development of most superior quality and accessible modern human medicines [58,59]. It has been reported that glands and organs harvested from slaughtered animals such as adrenal, parathyroid, pituitary, thyroid, ovaries, pancreas and testes are responsible for many of the hormones and enzymes used in the medical field sustainability nowadays [58]. Medicinal products that can be procured from animal glands are epinephrine, oestrogens, progesterone, insulin, trypsin, parathyroid hormone, adrenocorticotropic hormone (ACTH), somatotropin, thyroid stimulating hormone, testosterone and thyroxin [12]. Under-utilization of these by-products could lead to loss of potential incomes and result in the additional cumulative rate of discarded products. 
Blood is a red fluid comprising a mixture of cellular and plasma fraction (red blood cells, white blood cells and platelets). It represents about $4 \%$ of animal live weight or $6-7 \%$ of the lean meat content of the carcass $[60,61]$. Blood is rich in iron, proteins and bioactive compounds which are suitable for human and livestock use [62]. Blood proteins are easily accessible, edible and available in different forms, mainly as a liquid, frozen and dried. In the food industry, blood is used as binding agents, colour enhancers, emulsifiers, fat replacers and meat curing agents $[18,63]$. Plasma product (spray dried plasma) has been well integrated into food industry due to its foaming and leavening properties [64]. Besides, many cultures also consume blood as food or in combination with meat and other ingredients such as in blood sausage, black puddings and pancakes [62]. In feed industry, blood is used in the production of blood meal for feeding livestock and pets [18,65]. In medicine, blood is usually processed and used as a medium for the growth of probiotic bacteria (bovine plasma), the raw material for pharmaceutical porphyrin derivative production, a precursor to thrombin production and purification, the active ingredient in topical surgical hemostatic applications, and a reagent for routine blood clotting in serology laboratories [65]. When blood is collected from any animal, it is compulsory that such animal should be free from disease before the blood can be consumed or processed into food. However, blood or blood-related products are prohibited by a certain group of people who avoid blood-tainted foods due to religious, ethical, traditional and/or health reasons [64].

Animal horns contain keratin for the production of trophies, decorative objects, musical instruments and drinking vessels. The hooves and horns of animals have an abundant quantity of keratin, a protein used as hair care products. Likewise, collagen, gelatine and glue can be extracted from bone, hoof and horn. The extracted gelatine can be used for the treatment of digestive problems, ulcer, muscular disorders and nails growth [5]. Meat and bone meal (MBM) in animal diet remains a protein source because of its available essential amino acids, minerals and vitamins. On the other hand, the use of MBM became restricted in countries that experienced mad cow disease epidemics due to health concerns [66]. Like any other gland, bile is extracted either in liquid or dry form. Bile extracts contain proteins, prednisone, cortisone, acids and pigments that are important for medicinal and pharmaceutical purposes such as the treatment of constipation and indigestion [67]. In the poultry industry, feathers are epidermal growths that form the outer covering on poultry animals. Feathers are commonly used to stuff mattresses, pillows, dusters and in the manufacturing of automobiles accessories. They are among the most complex integumentary structures that produce keratin proteins in vertebrates. "Keratins are insoluble proteins (scleroproteins) which are resistant to physical, chemical and biological actions due to the resistance of proteolytic degradation" [68]. Thus, keratinase-producing microorganisms have been reported to degrade feathers into usable poultry feed and can be utilised for biogas production [68]. More so, application of high-pressure heat and steam has been shown to hydrolyze feathers into usable cysteine-rich, high protein product which has $60 \%$ digestibility [69]. These degraded feathers can be used to produce fertiliser because of its high protein and nitrogen content [70]. Furthermore, chicken feathers can be used for the production of strong thermoplastic products (such as polyethylene nylon, polyvinyl chloride and polystyrene) when processed with chemicals such as methyl acrylate [71].

\section{Industrial Usage of IEBPs}

\subsection{Biogas Industry}

Abattoirs generate an enormous quantity of waste products in the form of solid and liquid wastes which are responsible for severe environmental degradation if not well handled [72]. The usage of abattoir wastes as secondary fuel through thermal recycling in power plants has been reported to be achievable [73]. In spite of this, cattle manure, poultry litter and pig waste are also important for biogas and electric power production [74] while solid waste generated from abattoirs and meat processing is used as fuel in the cyclonic combustor [75]. 


\subsection{Cosmetic and Fabric Industry}

After the removal of hides and skin from slaughtered animal in the abattoir, it is necessary to cure the skin to prevent microbial and enzymatic decomposition [74]. The by-product such as hide and skin provides raw materials for industrial processing and export in many countries around the world. Common products from hides and skin are cosmetics, shoes, belts, car seats, bags, keratin and gelatine [76].

\subsection{Pharmaceutical Industry}

Chemical and biochemical extracts present in animal glands and organs which are contained as a portion in the syntheses of enzymes, hormones, pigments and vitamins are desirable and excellent products in the pharmaceutical, food and cosmetic industries [5]. Some preliminary research suggests that the use of these extracts may be helpful in treating various medical conditions such as hepatitis, building healthy red blood cells, treating chronic liver diseases, preventing liver damage, regenerating liver tissue, and treating certain cancers and other viral infections [4,67]. The liver extract contains vitamins and minerals such as calcium, copper, phosphorus and iron sold in either powdered or tablet form. Heparin extracted from the lungs and small intestine is a prescribed anticoagulant drug (Table 1) used to prevent blood clotting during surgery and in organ transplants [67]. The adrenal gland is for the production of steroid drugs, insulin from pancreas helps to treat diabetic patients while glucagon is important to treat overdose or low sugar [67].

Table 1. Common uses of animal by-products.

\begin{tabular}{|c|c|c|c|}
\hline $\begin{array}{c}\text { Animal } \\
\text { By-Products }\end{array}$ & Reprocessed Products & Major Uses & References \\
\hline Hides and Skin & $\begin{array}{l}\text { Cured hides \& skin. } \\
\text { Leather \& Textiles }\end{array}$ & $\begin{array}{l}\text { Leather clothes, belts, car and household upholsteries, bags, } \\
\text { footwear, drums, luggage, wallets, sports goods, gelatine etc. }\end{array}$ & {$[5,67,74,77-79]$} \\
\hline Hoof and horns & $\begin{array}{l}\text { Hoof \& horn meal } \\
\text { Gelatin and } \\
\text { keratin extraction }\end{array}$ & $\begin{array}{l}\text { Combs, buttons, plates, souvenirs, } \\
\text { Fertilizer, Collagen, glue, gelled food products, foaming in } \\
\text { fire extinguishers }\end{array}$ & {$[67,80,81]$} \\
\hline Blood & $\begin{array}{l}\text { Pharmaceutical products } \\
\text { Blood meal }\end{array}$ & $\begin{array}{l}\text { Catgut, tennis strips, blood sausages or pudding, fertilisers, } \\
\text { animal feeds, emulsifier and stabilizer }\end{array}$ & {$[5,61,74,79,84,85]$} \\
\hline Intestine & $\begin{array}{l}\text { Sausage casings } \\
\text { Surgical sutures } \\
\text { Musical instruments }\end{array}$ & $\begin{array}{l}\text { Sports guts, musical strings, prosthetic materials, collagen sheets, } \\
\text { burn dressing, strings for musical instruments, sausage casings, } \\
\text { human food, pet food, meat meal, tallow, casings }\end{array}$ & {$[5,12,18,84,86]$} \\
\hline Hair/Wool & $\begin{array}{l}\text { Textiles } \\
\text { Extraction of keratin }\end{array}$ & $\begin{array}{l}\text { Cloths or woven fabrics, mattress, keratin, carpets, } \\
\text { knitted apparels, insulators }\end{array}$ & [88-91] \\
\hline
\end{tabular}

\section{Utilization of Blood and Dried Rumen Digesta as Feed Ingredient}

Rumen contents, which are commonly known as "digesta", are considered as waste, but when re-processed or utilised, can become a product of high significance and economic value for the livestock industry [92]. The recovery of rumen digesta from ruminant animals in abattoirs offers a great opportunity as an alternate source of nutrients to complement the prevailing limited feed resources $[92,93]$. However, many studies do not encourage rumen digesta to be fed alone to livestock but rather to be supplemented with other feed ingredients at a recommended rate during feed formulation [11,94-96]. The chemical composition of dried rumen digesta, blood meal and their mixture has drawn the interest of nutritionists to use them as cheaper feedstuff [11,94-96]. On the other hand, rumen content and blood are environmentally unfavourable to life, causing air pollution, ground water pollution and eutrophication if not handled properly. Conversion of these IEBPs into livestock feed can enhance the flexibility of feed formulation and lessen environmental pollution [97]. 
It was pointed out that the use of dried rumen digesta as feed ingredients has no harmful effect on growth performance of the animals [98]. A mixture of blood and rumen content is a good source of feed ingredients in poultry ration, catfish ration, quail ration, lamb ration and cattle ration, which are significant with no adverse effects on animals [96,99-103]. When a suitable processing method is adopted, it reduces the amount of microorganisms present in the dried rumen digesta and reduces environmental pollution to a minimum level $[102,104,105]$.

\section{Nutritional Benefits of Feeding Rumen Content to Livestock}

Rumen digesta are usually processed by applying light heat or sun-drying before utilisation in feed formulation. The mixing of dry rumen digesta (DRD) with dried blood can improve the protein content of the ration when used as feed ingredients. The availability of amino acid contents and other compounds retained after processing depends on the intensity of heat applied on the rumen digesta [104]. Dry rumen digesta have been administered as feedstuff at varying levels, on different animal species (Table 2). Most of the studies conducted in the evaluation of DRD on the performance of livestock were carried out in Central Africa (Cameroon), North Africa (Egypt and Sudan) East Africa (Ethiopia), West Africa (Nigeria), Asia Middle East (Saudi Arabia), South East Asia (Thailand) and South Asia (India). Dried rumen digesta may vary in their proximate composition because of the different chemical composition of preferred pastures consumed by different animal species [94]. The dry matter (DM) of dried rumen digesta ranges from 13.36 to $98.4 \%$, crude protein (CP) 11.38 to $19.6 \%$ and crude fibre (CF) 15.3 to $41.84 \%$ (Table 2). In view of this, DRD was mixed with other feedstuffs to give value addition, increase palatability and enhance better efficiency [106].

Table 2. Chemical composition of cattle dried rumen contents from different countries.

\begin{tabular}{ccccccccccccc}
\hline Country & $\begin{array}{c}\text { Animal } \\
\text { Type }\end{array}$ & $\begin{array}{c}\text { DM } \\
\mathbf{\%}\end{array}$ & $\begin{array}{c}\text { CP } \\
\mathbf{\%}\end{array}$ & $\begin{array}{c}\text { EE } \\
\mathbf{\%}\end{array}$ & $\begin{array}{c}\text { CF } \\
\mathbf{\%}\end{array}$ & $\begin{array}{c}\text { ASH } \\
\mathbf{\%}\end{array}$ & $\begin{array}{c}\mathbf{N F E} \\
\mathbf{\%}\end{array}$ & $\begin{array}{c}\text { NDF } \\
\mathbf{\%}\end{array}$ & $\begin{array}{c}\text { ADF } \\
\%\end{array}$ & $\begin{array}{c}\text { CA } \\
\%\end{array}$ & $\begin{array}{c}\mathbf{P} \\
\%\end{array}$ & References \\
\hline Cameroon & Broiler & 92.44 & 15.21 & 7.81 & 41.84 & 9.25 & - & - & - & - & - & {$[107]$} \\
Egypt & Duck & 91.3 & 18.53 & 7.81 & 28.28 & 9.25 & 35.97 & - & - & 0.7 & 0.69 & {$[108]$} \\
India A & Quail & 92.64 & 18.26 & 3.6 & 24.99 & 14.47 & - & - & - & - & - & {$[103]$} \\
India B & Goat & 90.5 & 12.8 & - & - & - & - & 78.7 & -54.5 & - & - & {$[95]$} \\
Nigeria A & Rabbit & 91.8 & 11.38 & 6.1 & 24 & 8.11 & 42.21 & - & - & - & - & {$[94]$} \\
Nigeria B & Broiler & 81.8 & 18.52 & 8.79 & 15.3 & 7.6 & 38.39 & - & - & - & - & {$[109]$} \\
Saudi Arabia & Lamb & 13.36 & 14.2 & 1.7 & - & 11.6 & - & 59.2 & 36.7 & - & - & {$[110]$} \\
\hline
\end{tabular}

$\mathrm{DM}=$ dry matter, $\mathrm{EE}=$ ether extract, $\mathrm{CF}=$ crude fiber, $\mathrm{CP}=$ crude protein, NFE = nitrogen free extract energy, $\mathrm{Ca}=$ calcium, $\mathrm{P}=$ phosphorus, $\mathrm{NDF}=$ neutral detergent fiber, $\mathrm{ADF}=$ acid detergent fibre.

\subsection{Broilers and Layers}

Esonu et al. [111] in their study reported that broiler birds fed a diet containing dried bovine blood and rumen digesta mixture at varying levels of $0 \%, 5 \%, 10 \%, 15 \%$ and $20 \%$ generally had better feed intake, body weight gain, organ weight and nutrient utilization values compared to the control group. Similarly, Makinde et al. [112] observed that broiler chickens fed sun-dried rumen and content blood meal at $5 \%, 10 \%$ and $15 \%$ levels had higher carcass yields and lower feed cost per unit weight gain than the control group. Uchegbu et al. [109] highlighted that feed intake and weight gain of the broilers fed with dried rumen digesta increased, due to increase in high fibre and crude protein content of the diet which stimulated the birds to eat more to meet up with their energy requirement for swift growth and development. Therefore, Uchegbu et al. [109] also concluded in their study that the use of DRD as supplements in the diets of broiler provides cheaper cost of feed per kilogramme of meat produced and this idea is practical as an alternate source of feed in economic terms. Colette et al. [107] in their study found that the diet with 5\% DRD inclusion and a mixture of castor oil seed cake with DRD at 25\% inclusion level significantly influence the juiciness and consumer preference of broiler meat compared to the control group. As a result of this, the meat quality indicator of broilers fed with DRD is preferable to that of the broilers in the control diet, however, birds that were fed castor oil seed 
cake at $15 \%$ inclusion in the diet performed better. However, the colour, tenderness, juiciness, flavour and acceptability of the carcass quality of the boilers fed with DRD with or without enzyme inclusion were not different from each other [11]. Furthermore, when dry rumen digesta was supplemented with other feed ingredients in broiler diets, there were no side effect on the performance and biochemical quality of plasma in broiler chicks [110].

In a similar study by Makinde et al. [112] where chemical composition of dried rumen content with blood meal and its effect on broiler performance were undertaken, the results showed that birds fed with dried rumen content with blood meal at $0,5 \%$, and $10 \%$ had higher feed intake than birds fed with $15 \%$ rumen content with blood meal. For this reason, the performance of the broilers revealed that the final body weight, feed conversion ratio, and daily weight gain were higher at $10 \%$ inclusion level. As a result of this, the feed cost per unit weight gain was cheaper for all rumen content with blood meal while mortality was not influenced.

Furthermore, Gebrehawariat et al. [113] reported that layers that were fed with diets containing dried rumen digesta had better performance in terms of increase in egg weight, improved yolk colour and better chick quality performance, while the blood performance of the chicken layers was within the normal range. However, the body weight gain is not in agreement with Onu et al. [114] who reported an overall increase in the growth rate as DRD inclusion increases.

\subsection{Sheep}

In recent years, Osman et al. [96] reported a consistent increase in feed intake and feed conversion efficiency in sheep as the inclusion level of DRD in the diet increases. In this regard, sheep fed with $10 \%$ DRD had the highest weight gain, while weight gain was the lowest in the animals fed with no dried rumen content. The final body weights were $30.27,31.25$ and 31.75 in animals fed $0,5 \%$ and $10 \%$ DRD, respectively, but there were no significant differences between the weights.

\subsection{Cattle}

Cherdthong et al. [102] also found that the replacement of soya bean meal with $100 \%$ dried rumen digesta (DRD) as feed ingredients in cattle ration helped to enhance the intake of rice straw compared to other diets.

\subsection{Lamb}

Abouheif et al. [110] in their study reported no significant difference in the growth performance, hot carcass weight and dressing percentage of lambs fed with a dietary mixture of rumen contents and barley mixture at ratio 4:1 compared to the control group.

\subsection{Quail}

Mishra et al. [103] also reported that the inclusion of solar dried blood and the ruminal digesta at varying levels of $0 \%, 5 \%, 10 \%, 15 \%, 20 \%, 25 \%$ and $30 \%$ to replace soybean meal in Japanese quail diets resulted in higher weight gains compared to the control group.

\subsection{Rabbit}

The replacement of maize with DRD at $0 \%, 12.5 \%, 25 \%$ levels in rabbit diet resulted in no significant difference in the hematological parameters when compared to the control, indicating that the DRD diet was able to supply the required nutrition to maintain the normal blood parameters and health status of the experimental animals [115]. A similar study was conducted by Mohammed et al. [116] where rabbits were fed a mixture of bovine blood and rumen content at different inclusion levels. It was reported that there was no significant difference in the daily weight gain of the rabbits, but an increase in daily feed intake was observed among the treatments. 


\subsection{Goat}

In a study conducted by Abbator et al. [117] where rumen digesta was supplemented with wheat offal at varying levels in goat diets, the results revealed that all the goats had higher dry matter intake due to the palatability of the diets. However, goats that were placed on the $25 \%$ of dried rumen digesta with $75 \%$ wheat offal had the highest daily weight gain due to better feed conversion ratio, low inclusion level of DRD and high metabolizable energy. This is in agreement with Khattab et al. [118] who reported earlier that the inclusion of DRD in the diets of ruminants had no negative effect on the palatability.

In addition, the safety of DRD in animal feed was assessed and the pathogenic potential of rumen contents was also determined. Mondal et al. [95] revealed that rumen bacteria are non-pathogenic due to the lack of the enterotoxin gene and thus will not be harmful if fed to animals. In view of this, when E. coli were counted in post-dumped rumen content, there was an initial increase in the number of E. coli which decreased subsequently, but Staphylococcus aureus increased in number, although the microbial load was within the recommended level. For this reason, Mondal et al. [95] concluded that rumen bacteria are non-pathogenic due to the lack of the enterotoxin gene, and thus will not be harmful if fed to animals.

\section{Concerns Associated with the Use of Inedible By-Products}

Production of animal feed through recycling of animal waste to ease cost of feed has been in operation for over forty years $[119,120]$. Initially, rendering of animal carcases was a routine practice in Europe and other countries before the outbreak of Bovine Spongiform Encephalopathy (BSE) in 1988 [121]. Bovine Spongiform Encephalopathy is an affiliate of the Transmissible Spongiform Encephalopathy (TSE), known as neurodegenerative disorders. The general point of BSE infection is through the ingestion of feed contaminated with animal protein infected by a prion agent. A prion is an infectious protein that modifies normal cellular proteins into a pathogenic form that impairs the central nervous system of animals $[122,123]$. Prions are impervious to processes that disintegrate nucleic acid and are responsible for the acquired form of neurodegenerative disease [124]. Typically, prions are often found in most vulnerable parts of the central nervous system (brain and spinal cord) and bone marrow $[125,126]$. In cattle, the symptoms of BSE are: change in temperament, aggression, lack of coordination, reduced milk yield and loss of appetite. In this regard, many studies have reported that contaminated animal tissues serve as the prion carriers [127-131]. For this reason, specified risk materials such as the brain, nerves attached to the brain and spinal cord are removed and separated from meat during processing in the abattoir in order to prevent the spread of BSE disease to animals and humans [132]. Furthermore in 2005, the Food and Drug Administration (FDA) agency proposed that the use of brains and spinal cords from cattle older than 30 months of age or cattle of any age not inspected and passed for human consumption should be prohibited in the food or feed of all animals [133]. This strategy has been successful in controlling the spread of BSE, and allows utilization of other inedible by-products, especially rumen digesta in animal feed. In fact, it is yet to be well established that either processed or unprocessed rumen digesta contains prions that can aid the spread of BSE.

\section{Heavy Metal Accumulation with the Use of Rumen Digesta}

The concentration of toxic metals in dried rumen content depends on exposure of forage crops eaten by the animals, soil content, human and natural activities. Unlike lead ( $\mathrm{Pb})$, cadmium $(\mathrm{Cd})$ is readily absorbed and circulated evenly in plant tissues [134]. Certain plants species have the ability to absorb heavy metals within their tissues and this may heighten the risk of contamination of the food chain [135]. Due to consumption of these contaminated pastures by ruminants, deposition of toxic metals in meat, tissues and organs may occur. Meats from animals raised on pastures close to mining areas have been reported to contain more heavy metals due to natural activity [136]. After the 
digestion of the contaminated forage in the animal, toxic metals are also excreted in their faeces [137]. The presence of heavy metals in the animal manure gives an idea that the forage or pasture consumed by the animal contains a certain level of these toxic metals [138]. For this reason, grazing and browsing animals are more exposed to toxic metals compared to other livestock and this may be residual in the rumen content [137]. Typically, about $90 \%$ of toxic metals are transferred through food consumption as a major pathway for human vulnerability $[139,140]$. For this reason, the potential for accumulation of heavy metals in the undigested rumen content should be investigated to determine its sustainability in food chain.

\section{Conclusions and Future Perspectives}

It is well known that EBPs and IEBPs have been fully explored in many industries for their benefits. Findings from this study have revealed that EBPs contain nutrients of high nutritional values and can be efficiently utilized as alternative protein sources to reduce the menace of malnutrition and food insecurity across the world. While the addition of IEBPs such as dried rumen content in livestock diet can be used as alternative feed ingredients to lessen prevailing cost and scarcity of feed materials which have high competition between animals and humans. If properly processed in livestock diets, dried rumen content can suitably fill the gap of non-conventional feed sources. Therefore, it could be better explained that most animal by-products are globally used adequately for humans, pets or animals except for rumen contents which has a great opportunity for better uses than the current practices. However, the limitation of DRD may be linked to the possibility of accumulation of heavy metals in the undigested rumen content that may be recycled into the animal feed. Consequently, residual toxic metals may be present in meats and especially offal, which are later consumed by humans. Toxic metal contamination in food has been held responsible for related problems in humans such as amnesia in adults, stunted growth in infants, reproductive problems, high blood pressure, nervous disorders, oligospermia in males, and abortion in females. Therefore, further investigation should be conducted on the presence of toxic metals in DRD and in meats from animals that have been fed with diets containing DRD.

Acknowledgments: Govan Mbeki Research Development Center (GMRDC), University of Fort Hare South Africa is appreciated for her financial support.

Author Contributions: This review article was conceived, written and completed mainly by Alao Babatunde. Falowo Andrew contributed conceptual thoughts and provided figures in this article. Chulayo Amanda was involved in re-structuring the body of the article. Muchenje Voster supervised, gave conceptual ideas and was fully involved in the proofreading of the final manuscript. All authors were involved in the completion of the submitted manuscript and in adjusting the manuscript according to the reviewers' comments. All authors read, agreed and approved the final manuscript.

Conflicts of Interest: The authors declare no conflict of interest.

\section{References}

1. Byers, T.; Nestle, M.; Mctiernan, A.; Doyle, C.; Currie-Williams, A.; Gansler, T.; Thun, M. American Cancer Society Guidelines on Nutrition and Physical Activity for Cancer Prevention: Reducing the Risk of Cancer with Healthy Food Choices and Physical Activity. CA Cancer J. Clin. 2002, 52, 92-119. [CrossRef] [PubMed]

2. Chikwanha, O.C.; Vahmani, P.; Muchenje, V.; Dugan, M.E.; Mapiye, C. Nutritional enhancement of sheep meat fatty acid profile for human health and wellbeing. Food Res. Int. 2017. [CrossRef]

3. Sans, P.; Combris, P. World meat consumption patterns: An overview of the last fifty years (1961-2011). Meat Sci. 2015, 109, 106-111. [CrossRef] [PubMed]

4. Liu, D.-C. Better Utilization of By-Products from the Meat Industry; Food and Fertilizer Technology Center: Taipei, Taiwan, 2002.

5. Irshad, A.; Sharma, B.D. Abattoir By-Product Utilization for Sustainable Meat Industry: A Review. J. Anim. Prod. Adv. 2015, 6, 681-696. 
6. Fayemi, P.O.; Muchenje, V.; Yetim, H.; Abdulatef, A. Targeting the Pains of Food Insecurity and Malnutrition Among Internally Displaced Persons with Nutrient Synergy and Analgesics in Organ Meat. Food Res. Int. 2016. [CrossRef]

7. Sheehy, J.; Elmido, A.; Centeno, G.; Pablico, P. Searching for New Plants for Climate Change. J. Agric. Meteorol. 2005, 60, 463-468. [CrossRef]

8. Food and Agriculture Organization of the United Nations (FAO). Meat Consumption. 2014. Available online: http:/ / www.fao.org/ag/againfo/themes/en/meat/background.html (accessed on 25 November 2014).

9. Rosa, G.T.; Pires, C.C.; da Silva, J.H.S.; da Motta, O.S. Proporções E Coeficientes De Crescimento Dos Não-Componentes Da Carcaça De Cordeiros E Cordeirasemdiferentesmétodos De Alimentação. Revistabrasileira De Zootecnia 2002, 31, 2290-2298. [CrossRef]

10. Ockerman, H.W.; Basu, L. By-Products. In Encyclopedia of Meat Sciences, 2nd ed.; Devine, C., Dikeman, M., Eds.; Elsevier Academic Press: Amsterdam, The Netherlands; London, UK, 2004; pp. 104-112.

11. Elfaki, M.O.A.; Abdelatti, K.A.; Malik, H.E.E. Effect of Dietary Dried Rumen Content on Broiler Performance, Plasma Constituents and Carcass Characteristics. Glob. J. Anim. Sci. Res. 2014, 3, 264-270.

12. Marti, D.L.; Johnson, R.J.; Mathews, K.H., Jr. Where's The (Not) Meat? By-Products from Beef and Pork Production. J. Curr. Issues Glob. 2012, 4, 397.

13. Pérez-Alvarez, J.A.; Sayas-Barberá, M.E.; Sendra, E.; Fernández-López, J. Color Measurements on Edible Animal By-Products and Muscle Based Foods. In Handbook of Analysis of Edible Animal By-Products; Nollet, L.M.L., Toldrá, F., Eds.; CRC Press: Boca Raton, FL, USA, 2011; pp. 87-102.

14. Alexandre, G.; Liméa, L.; Nepos, A.; Fleury, J.; Lallo, C.; Archimede, H. The Offal Components and Carcass Measurements of Creole Kids of Guadeloupe under Various Feeding Regimes. Development 2010, $22,5$.

15. Yibar, A.; Selcuk, O.; Senlik, B. Major Causes of Organ/Carcass Condemnation and Financial Loss Estimation in Animals Slaughtered At Two Abattoirs in Bursa Province, Turkey. Prev. Vet. Med. 2015, 118, $28-35$. [CrossRef] [PubMed]

16. Gonulalan, Z.; Kose, A.; Yetim, H. Effects of Liquid Smoke on Quality Characteristics of Turkish Standard Smoked Beef Tongue. Meat Sci. 2004, 66, 165-170. [CrossRef]

17. Nollet, L.M.; Toldrá, F. Handbook of Analysis of Edible Animal By-Products; CRC Press: Boca Raton, FL, USA, 2011.

18. Toldrá, F.; Aristoy, M.C.; Mora, L.; Reig, M. Innovations in Value-Addition of Edible Meat By-Products. Meat Sci. 2012, 92, 290-296. [CrossRef] [PubMed]

19. Vanheerden, S.M.; Morey, L. Nutrient Content of South African C2 Beef Offal. J. Food Meas. Charact. 2014, 8, 249-258. [CrossRef]

20. Masese, L.; Waweru, J. Knowledge, Attitudes and Practices Study on Offal Consumption among the Somali Population. Available online: http:/ / www.ennonline.net/fex/41/knowledge (accessed on 9 May 2017).

21. Abu-Salem, F.M.; Abou Arab, E.A. Chemical Properties, Microbiological Quality and Sensory Evaluation of Chicken and Duck Liver Paste (Foiegras). Grasas Y Aceites 2010, 61, 126-135. [CrossRef]

22. Lorenzo, J.M.; Pateiro, M. Influence of Fat Content on Physico-Chemical and Oxidative Stability of Foal Liver Pâté. Meat Sci. 2013, 95, 330-335. [CrossRef] [PubMed]

23. Xiong, G.; Han, M.; Kang, Z.; Zhao, Y.; Xu, X.; Zhu, Y. Evaluation of Protein Structural Changes and Water Mobility in Chicken Liver Paste Batters Prepared With Plant Oil Substituting Pork Back-Fat Combined With Pre-Emulsification. Food Chem. 2016, 196, 388-395. [CrossRef] [PubMed]

24. Jones, A.K.; Rigby, D.; Burton, M.; Millman, C.; Williams, N.J.; Jones, T.R.; Wigley, P.; O’Brien, S.J.; Cross, P.; Consortium, E. Restaurant Cooking Trends and Increased Risk for Campylobacter Infection. Emerg. Infect. Dis. 2016, 22, 1208. [CrossRef] [PubMed]

25. Ercan, P.; El, S.N. Changes in Content of Coenzyme Q10 in Beef Muscle, Beef Liver and Beef Heart with Cooking and In Vitro Digestion. J. Food Compos. Anal. 2011, 24, 1136-1140. [CrossRef]

26. Li, R.R.; Yu, Q.L.; Han, L.; Cao, H. Nutritional Characteristics and Active Components in Liver from Wagyu $\times$ Qinchuan Cattle. Korean J. Food Sci. Anim. Resour. 2014, 32, 214. [CrossRef] [PubMed]

27. Chan, W. (Ed.) Meat Poultry and Game. In Fifth Supplement to the Fifth Edition of McCance and Widdowson's. The Composition of Foods; Royal Society of Chemistry: London, UK, 1995.

28. Enser, M.; Hallett, K.G.; Hewett, B.; Fursey, G.A.J.; Wood, J.D.; Harrington, G. The Polyunsaturated Fatty Acid Composition of Beef and Lamb Liver. Meat Sci. 1998, 49, 321-327. [CrossRef] 
29. Seong, P.N.; Park, K.M.; Cho, S.H.; Kang, S.M.; Kang, G.H.; Park, B.Y.; Moon, S.S.; Ba, H.V. Characterization of Edible Pork By-Products By Means of Yield and Nutritional Composition. Korean J. Food Sci. Anim. Resour. 2014, 34, 297. [CrossRef] [PubMed]

30. Zouari, N.; Fakhfakh, N.; Amara-Dali, W.B.; Sellami, M.; Msaddak, L.; Ayadi, M.A. Turkey Liver: Physicochemical Characteristics and Functional Properties of Protein Fractions. Food Bioprod. Process. 2011, 89, 142-148. [CrossRef]

31. Steen, L.; Glorieux, S.; Goemaere, O.; Brijs, K.; Paelinck, H.; Foubert, I.; Fraeye, I. Functional Properties of Pork Liver Protein Fractions. Food Bioprocess Technol. 2016, 9, 970-980. [CrossRef]

32. Purchas, R.W.; Aungsupakorn, R. Further Investigations into the Relationship between Ultimate Ph and Tenderness for Beef Samples from Bulls and Steers. Meat Sci. 1993, 34, 163-178. [CrossRef]

33. Miller, J.L. Iron Deficiency Anemia: A Common and Curable Disease. Cold Spring Harb. Perspect. Med. 2013, 3, 011866. [CrossRef] [PubMed]

34. Gaudy, N.; Landis, J. Effect of Different Heat Treatments of Some Carcasses Parts on the Total Amino Acids Content and that in Enzyme Hydrolysates. Mitteilungen-aus-dem-Gebiete-der-Lebensmitteluntersuchungund-Hyg. 1973, 64, 133-138.

35. Arafa, A.S. Pickled Chicken Gizzards 1. Acceptability and Proximate Analysis. Poult. Sci. 1977, 56, $1014-1017$. [CrossRef]

36. Daniel, I.E. Proximate Composition and Levels of Trace Metals in Chicken Meat Consumed in Uyo Metropolis, Akwaibom State. Ann. Food Sci. Technol. 2015, 16, 262-266.

37. Byun, M.W.; Lee, J.W.; Jo, C.; Yook, H.S. Quality Properties of Sausage Made With Gamma-Irradiated Natural Pork and Lamb Casing. Meat Sci. 2001, 59, 223-228. [CrossRef]

38. Nakyinsige, K.; Man, Y.B.C.; Sazili, A.Q. Halal Authenticity Issues in Meat and Meat Products. Meat Sci. 2012, 91, 207-214. [CrossRef] [PubMed]

39. Madruga, M.S.; Dos Santos, M.N.; Costa, R.G.; De Medeiros, A.N.; Do Egypto, R.Q.; Schuller, A.R.; Albuquerque, C.L.C.; Galvão, M.S.; Cavalcanti, R.N.; Campos, R.A. Fat Components from Precooked "Buchada": An Edible Goat Meat By-Product Componentes De La Grasa De "Buchada" Precocida: Un Subproducto Comestible De La Carne De Cabra. CYTA J. Food 2007, 5, 265-270. [CrossRef]

40. Tremblay, S. The Advantages of Eating Cow Tongue. 2011. Available online: http://www.livestrong.com/ article/441526-how-to-cook-with-lamb-tongue/ (accessed on 18 July 2016).

41. Ranken, M.D. Handbook of Meat Product Technology; Blackwell Science: Oxford, UK, 2000.

42. Holman, R.T.; Hofstetter, H.H. The Fatty Acid Composition of the Lipids from Bovine and Porcine Reproductive Tissues. J. Am. Oil Chem. Soc. 1965, 42, 540-544. [CrossRef] [PubMed]

43. Pucciarelli, D.L.; Friesen, C.A.; Schroeder, A.L. New Culinary Uses for Pork Testicles from Immunologically Castrated Male Pigs. FASEB J. 2012, 26, 636-646.

44. Rotenberg, R. Udders, Penises, and Testicles. Ethnology 2008, 47, 123-128.

45. Florek, M.; Litwińczuk, Z.; Skałecki, P.; Kędzierska-Matysek, M.; Grodzicki, T. Chemical Composition and Inherent Properties of Offal from Calves Maintained Under Two Production Systems. Meat Sci. 2012, 90, 402-409. [CrossRef] [PubMed]

46. Hoffman, L.C.; Laubscher, L.L.; Leisegang, K. Nutritional Value of Cooked Offal Derived from Free-Range Rams Reared in South Africa. Meat Sci. 2013, 93, 696-702. [CrossRef] [PubMed]

47. Puschner, B.; Thurmond, M.C.; Choi, Y.K. Influence of Age and Production Type on Liver Copper Concentrations in Calves. J. Vet. Diagn. Investig. 2004, 16, 382-387. [CrossRef] [PubMed]

48. Zawacka, M.; Murawska, D.; Gesek, M. The Effect of Age and Castration on the Growth Rate, Blood Lipid Profile, Liver Histology and Feed Conversion in Green-Legged Partridge Cockerels and Capons. Animal 2016, 11, 1-10. [CrossRef] [PubMed]

49. Abdelmageed, M.E.I.; Sulieman, A.M.E.; Abdalla, H.O.; Salih, G.E. Effects of Incorporating Chicken's Gizzards and Abdominal Fat in the Quality of Burger Meat Product. J. Microbiol. Res. 2014, 2, 68-71.

50. Meatupdate, Storage Life of Meat. 2002. Available online: http://www.meatupdate.csiro.au/storage-life-ofmeat.pdf (accessed on 18 May 2016).

51. Cohen, N.; Ennaji, H.; Hassa, M.; Karib, H. The Bacterial Quality of Red Meat and Offal in Casablanca (Morocco). Mol. Nutr. Food Res. 2006, 50, 557-562. [CrossRef] [PubMed] 
52. Brasil, L.; Queiroz, A.; Silva, J.; Bezerra, T.; Arcanjo, N.; Magnani, M.; Souza, E.; Madruga, M. Microbiological and Nutritional Quality of the Goat Meat By-Product "Sarapatel". Molecules 2014, 19, 1047-1059. [CrossRef] [PubMed]

53. Lee, J.W.; Lee, Y.J. The Bacterial Quality and Prevalence of Foodborne Pathogens of Edible Offals from Slaughterhouses in Gyeongsangbuk-Do. J. Prev. Vet. Med. 2016, 40, 53-58. [CrossRef]

54. Kijlstra, A.; Jongert, E. Control of the Risk of Human Toxoplasmosis Transmitted By Meat. Int. J. Parasitol. 2008, 38, 1359-1370. [CrossRef] [PubMed]

55. Falowo, A.B.; Muchenje, V.; Hugo, A. Accepted Author Version of the Manuscript: Effect of Sous-Vide Technique on Fatty Acid and Mineral Compositions of Beef and Liver from Bonsmara and Non-Descript Cattle. Ann. Anim. Sci. 2017, 17, 565-580. [CrossRef]

56. Sharma, H.; Giriprasad, R.; Goswami, M. Animal Fat-Processing and Its Quality Control. J. Food Process. Technol. 2013, 4, 252.

57. Department of Agriculture, Forestry and Fisheries (DAFF). A Profile of the South African Hides, Skins and Leather Market Value Chain. 2012. Available online: http://www.nda.agric.za/docs/amcp/skins2012.pdf (accessed on 28 August 2016).

58. Aberle, E.D.; Forrest, J.C.; Gerrard, D.E.; Mills, E.W.; Hedrick, H.B.; Judge, M.D.; Merkel, R.A. Conversion of Muscle to Meat and Development of Meat Quality. In Principles of Meat Science, 4th ed.; Kendall and Hunt: Dubuque, IA, USA, 2001; pp. 83-107.

59. Costa-Neto, E.M. Animal-Based Medicines: Biological Prospection and the Sustainable Use of Zootherapeutic Resources. An. Acad. Bras. Ciênc. 2005, 77, 33-43. [CrossRef] [PubMed]

60. Wismer-Pedersen, J. Use of Haemoglobin in Foods: A Review. Meat Sci. 1988, 24, 31-45. [CrossRef]

61. Bah, C.S.; Bekhit, A.E.D.A.; Carne, A.; Mcconnell, M.A. Slaughterhouse Blood: An Emerging Source of Bioactive Compounds. Compr. Rev. Food Sci. Food Saf. 2013, 12, 314-331. [CrossRef]

62. Davidson, A. The Oxford Companion to Food, 3rd ed.; Oxford University Press: Oxford, UK, 2014.

63. Ofori, J.A.; Hsieh, Y.H.P. Issues Related to the Use of Blood in Food and Animal Feed. Crit. Rev. Food Sci. Nutr. 2014, 54, 687-697. [CrossRef] [PubMed]

64. Hsieh, Y.H.P.; Ofori, J.A. Blood-Derived Products for Human Consumption. Revel. Sci. 2011, 1, $14-21$.

65. Bah, C.S.; Bekhit, A.E.D.A.; Carne, A.; Mcconnell, M.A. Composition and Biological Activities of Slaughterhouse Blood from Red Deer, Sheep, Pig and Cattle. J. Sci. Food Agric. 2016, 96, 79-89. [CrossRef] [PubMed]

66. Möller, K. Assessment of Alternative Phosphorus Fertilizers for Organic Farming: Meat and Bone Meal. Available online: https://shop.fibl.org/chde/mwdownloads/download/link/id/738/ (accessed on 20 February 2017).

67. Jayathilakan, K.; Sultana, K.; Radhakrishna, K.; Bawa, A.S. Utilization of Byproducts and Waste Materials from Meat, Poultry and Fish Processing Industries: A Review. J. Food Sci. Technol. 2012, 49, 278-293. [CrossRef] [PubMed]

68. Deivasigamani, B.; Alagappan, K.M. Industrial Application of Keratinase and Soluble Proteins from Feather Keratins. J. Environ. Biol. 2008, 29, 933-936. [PubMed]

69. Dios, D. Fishmeal Replacement with Feather-Enzymatic Hydrolyzates Co-Extruded with Soya-Bean Meal in Practical Diets for the Pacific White Shrimp (Litopenaeus vannamei). Aquac. Nutr. 2001, 19, 143-151.

70. Davidson, I. Diverse Uses of Feathers With Emphasis on Diagnosis of Avian Viral Infections and Vaccine Virus Monitoring. Revistabrasileira De Ciênciaavícola 2009, 11, 139-148. [CrossRef]

71. Sharma, S.; Gupta, A. Sustainable Management of Keratin Waste Biomass: Applications and Future Perspectives. Braz. Arch. Biol. Technol. 2016, 59, e16150684. [CrossRef]

72. Cuadros, F.; López-Rodríguez, F.; Ruiz-Celma, A.; Rubiales, F.; González-González, A. Recycling, Reuse and Energetic Valuation of Meat Industry Wastes in Extremadura (Spain). Resour. Conserv. Recycl. 2011, 55, 393-399. [CrossRef]

73. Arvanitoyannis, I.S.; Ladas, D. Meat Waste Treatment Methods and Potential Uses. Int. J. Food Sci. Technol. 2008, 43, 543-559. [CrossRef]

74. Ur Rahman, U.; Sahar, A.; Khan, M.A. Recovery and Utilization of Effluents from Meat Processing Industries. Food Res. Int. 2014, 65, 322-328. [CrossRef] 
75. Virmond, E.; Schacker, R.L.; Albrecht, W.; Althoff, C.A.; De Souza, M.; Moreira, R.F.; José, H.J. Organic Solid Waste Originating from the Meat Processing Industry as an Alternative Energy Source. Energy 2011, 36, 3897-3906. [CrossRef]

76. Benjakul, S.; Oungbho, K.; Visessanguan, W.; Thiansilakul, Y.; Roytrakul, S. Characteristics of Gelatin from the Skins of Bigeye Snapper, Priacanthustayenus and Priacanthusmacracanthus. Food Chem. 2009, 116, 445-451. [CrossRef]

77. Tesfaye, J.; Dubie, T.; Terefe, G. Evaluation of Hide and Skin Market Chains in and around Shashemene Town. Scientia 2015, 10, 119-126.

78. Hekal, S.A. Histological Study of the Skin and Leather Characteristics in Two Types of Arabian Camels (Camelus dromedarius). J. Am. Sci. 2014, 10, 41-48.

79. Department of Agriculture Forestry and Fisheries (DAFF). A Profile of the South African Hides. Skins and Leather Market Value Chain. 2011. Available online: http://www.daff.gov.za/docs/amcp/ hidesskinamvcp2010-11.pdf (accessed on 27 November 2016).

80. Omole, D.O.; Ogbiye, A.S. An Evaluation of Slaughterhouse Wastes in South-West Nigeria. Am. J. Environ. Prot. 2013, 2, 85-89. [CrossRef]

81. Karthikeyan, R.; Balaji, S.; Sehgal, P.K. Industrial Applications of Keratins-A Review. Am. J. Sci. Ind. Res. 2007, 66, 710 .

82. Gue, D.E. Guidelines for Livestock Marketing and Processing Component in Bank Funded Projects; World Bank: Washington, DC, USA, 1998.

83. Nhari, R.M.H.R.; Ismail, A.; Man, C.; Yaakob, B. Analytical Methods for Gelatin Differentiation from Bovine and Porcine Origins and Food Products. J. Food Sci. 2012, 77, 42-46. [CrossRef] [PubMed]

84. Quality Meat Scotland (QMS). Recovering Value from the 5th Quarter and Reducing Waste. 2010. Available online: www.qmscotland.co.uk/sites/default/files/Added+Value+Topic+3+Edible+Offals.pdf (accessed on 17 January 2017).

85. Hyun, C.K.; Shin, H.K. Utilization of Bovine Blood Plasma Proteins for the Production of Angiotensin I Converting Enzyme Inhibitory Peptides. Process Biochem. 2000, 36, 65-71. [CrossRef]

86. Bhaskar, N.; Modi, V.K.; Govindaraju, K.; Radha, C.; Lalitha, R.G. Utilization of Meat Industry By-Products: Protein Hydrolysate from Sheep Visceral Mass. Bioresour. Technol. 2007, 98, 388-394. [CrossRef] [PubMed]

87. Deveau, I.; Dabbah, R.; Sutton, S. The USP Perspective to Minimize the Potential Risk of TSE Infectivity in Bovine-Derived Article Used in the Manufacture of Medical Products. Pharmacop. Forum 2004, 30, 1911-1921.

88. Scobie, D.R.; Grosvenor, A.J.; Bray, A.R.; Tandon, S.; Meade, W.J.; Cooper, A.M.B.A. Review of Wool Fibre Variation Across the Body of Sheep and the Effects on Wool Processing. Small Rumin. Res. 2015, 133, 43-53. [CrossRef]

89. Patrucco, A.; Cristofaro, F.; Simionati, M.; Zoccola, M.; Bruni, G.; Fassina, L.; Visai, L.; Magenes, L.; Mossotti, R.; Montarsolo, A.; et al. Wool Fibril Sponges with Perspective Biomedical Applications. Mater. Sci. Eng. 2016, 61, 42-50. [CrossRef] [PubMed]

90. Phua, S.H.; Cullen, N.G.; Dodds, K.G.; Scobie, D.R.; Bray, A.R. An Ovine Quantitative Trait Locus Affecting Fibre Opacity in Wool. Small Rumin. Res. 2015, 130, 122-126. [CrossRef]

91. Liu, H.; Ning, W.; Cheng, P.; Zhang, J.; Wang, Y.; Zhang, C. Evaluation of Animal Hairs-Based Activated Carbon for Sorption of Norfloxacin and Acetaminophen By Comparing With Cattail Fiber-Based Activated Carbon. J. Anal. Appl. Pyrolysis 2013, 101, 156-165. [CrossRef]

92. Amata, I.A. The Use of Non-Conventional Feed Resources (NCFR) for Livestock Feeding in the Tropics: A Review. J. Glob. Biosci. 2014, 3, 604-613.

93. Adedipe, N.O.; Sridhar, M.K.C.; Verma, M.; Wagner, A. Waste Management, Processing, and Detoxification. Ecosyst. Hum. Well-Being Policy Responses 2005, 3, 313-334.

94. Togun, V.A.; Farinu, G.O.; Ojebiyi, O.O.; Awotunde, A.I. Effect of Replacing Maize with a Mixture of Rumen Content and Blood Meal on the Performances of Growing Rabbits: Initial Study with Mash Feed. World Rabbit Sci. 2010, 17, 21-26. [CrossRef]

95. Mondal, S.; Haldar, S.; Samanta, I.; Samanta, G.; Ghosh, T.K. Exploring Nutritive Potential of Undigested Rumen Contents as an Ingredient in Feeding of Goats. Anim. Nutr. Feed Technol. 2013, 13, 79-88.

96. Osman, A.A.; Elimam, M.E. Processed Animal Waste as a Feed for Sudanese Desert Lamb. Int. J. Adv. Multidiscip. Res. 2015, 2, 12-17. 
97. Ørskov, E.R. Animals in Natural Interaction with Soil, Plants, and People in Asia. Dev. Pract. 2007, 17, 272-278. [CrossRef]

98. Yitbarek, M.B.; Mersso, B.T.; Wosen, A.M. Effect of Dried Blood-Rumen Content Mixture (DBRCM) on Feed Intake, Body Weight Gain, Feed Conversion Ratio and Mortality Rate of SASSO C44 Broiler Chicks. J. Livest. Sci. 2016, 7, 139-149.

99. Dairo, F.A.S.; Aina, O.O.; Asafa, A.R. Performance Evaluation of Growing Rabbits Fed Varying Levels of Rumen Content and Blood Rumen Content Mixture. Niger. J. Anim. Prod. 2005, 32, 67-72.

100. Adeniji, A.A.; Balogun, O.O. Evaluation of Blood-Rumen Content Mixture in the Diets of Starter Chicks. Niger. J. Anim. Prod. 2001, 28, 153-157.

101. Adeniji, A.A.; Balogun, O.O. Utilisation of Flavour Treated Blood-Rumen Content Mixture in the Diets of Laying Hens. Niger. J. Anim. Prod. 2002, 29, 34-39.

102. Cherdthong, A.; Wanapat, M.; Saenkamsorn, A.; Waraphila, N.; Khota, W.; Rakwongrit, D.; Anantasook, N.; Gunun, N. Effects of Replacing Soybean Meal with Dried Rumen Digesta on Feed Intake, Digestibility of Nutrients, Rumen Fermentation and Nitrogen Use Efficiency in Thai Cattle Fed on Rice Straw. Livest. Sci. 2014, 169, 71-77. [CrossRef]

103. Mishra, J.; Abraham, R.J.; Rao, V.A.; Rajini, R.A.; Mishra, B.P.; Sarangi, N.R. Chemical Composition of Solar Dried Blood and the Ruminal Content and Its Effect on Performance of Japanese Quails. Vet. World 2015, 8, 82-87. [CrossRef] [PubMed]

104. Makinde, O.A.; Sonaiya, E.B. Determination of Water, Blood and Rumen Fluid Absorbencies of Some Fibrous Feedstuffs. Livest. Res. Rural Dev. 2007, 19, 156.

105. Agbabiaka, L.A.; Madubuike, F.N.; Amadi, S.A. Studies on Nutrients and Anti-Nutrients of Rumen Digesta from Three Most Domesticated Ruminants in Nigeria. Pak. J. Nutr. 2012, 11, 580.

106. Wilson, D. Methods of Disposal of Paunch Contents with Emphasis on Composting. In Inedible Meat By-Products; Pearson, A.M., Dutson, T.R., Eds.; Springer: Dordrecht, The Netherlands, 1992; pp. 265-281.

107. Colette, N.T.; Fotsa, J.C.; Etchu, K.A.; Ndamukong, K.J. Effects of Dried Rumen Content and Castor Oil Seed Cake Diets on Haematological Indices, Serum Biochemistry and Organoleptic Properties of Broiler Birds. Energy 2013, 43, 57-58.

108. Said, I.F.; Elkhair, R.M.A.; Shawky, S.M.; Abdelrahman, H.A.; Elfeki, M.A. Impact of Feeding Dried Rumen Content and Olive Pulp With Or Without Enzymes on Growth Performance, Carcass Characteristics and Some Blood Parameters of Molar Ducks. Int. J. Agric. Innov. Res. 2015, 4, 2319-2473.

109. Uchegbu, M.C.; Etuk, E.B.; Udedibie, A.B.I. Evaluation of Performance, Organ Characteristics and Economic Analysis of Broiler Finisher Fed Dried Rumen Digesta. Int. J. Poult. Sci. 2006, 5, 1116-1118.

110. Abouheif, M.A.; Kraidees, M.S.; Al-Selbood, B.A. The Utilization of Rumen Content-Barley Meal in Diets of Growing Lambs. Asian-Aust. J. Anim. Sci. 1999, 12, 1234-1240. [CrossRef]

111. Esonu, B.O.; Azubuike, J.C.; Udedibie, A.B.I.; Emenalom, O.O.; Iwuji, T.C.; Odoemenam, V. Evaluation of the Nutritive Value of Mixture of Fermented Bovine Blood and Rumen Digesta for Broiler Finisher. J. Nat. Sci. Res. 2011, 4, 2224-3186.

112. Makinde, O.; Sonaiya, B.; Adeyeye, S. Conversion of Abattoir Wastes into Livestock Feed: Chemical Composition of Sun-Dried Rumen Content Blood Meal and Its Effect on Performance of Broiler Chickens. Int. J. Poult. Sci. 2008, 12, 875-882.

113. Gebrehawariat, E.; Animut, G.; Urge, M.; Mekasha, Y. Sun-Dried Bovine Rumen Content (SDRC) as an Ingredient of A Ration for White Leghorn Layers. East Afr. J. Sci. 2016, 10, $29-40$.

114. Onu, P.N.; Otuma, M.O.; Odukwe, C.A.; Aniebo, A.O. Effects of Different Levels of Bovine Blood/Rumen Content Mixture on Productive Performance, Carcass Characteristics and Economics of Production of Finisher Broilers. Int. J. Food Agric. Vet. Sci. 2011, 1, 10-16.

115. Oluwafemi, R.A.; Iliyasu, A. Effects of Graded Levels of Rumen Digesta Based Diets With or Without Enzyme Supplementation on the Blood Chemistry of Weaner Rabbits. Int. J. Vet. Sci. Anim. Husb. 2016, 1, $43-46$.

116. Mohammed, G.; Igwebuike, J.U.; Alade, N.K. Performance of Growing Rabbits Fed Graded Levels of Bovine Blood-Rumen Content Mixture. Agric. Biol. J. N. Am. 2011, 2, 720-723. [CrossRef]

117. Abbator, F.I.; Kolo, U.M.; Taimako, A.R.; Kwaghe, A.L. Performance of Goats Fed Bovine Rumen Content and Wheat Offal as Supplement to Groundnut Haulms. Glob. J. Agric. Res. 2016, 4, 9-16.

118. Khattab, H.M.; Abdelmawla, S.M.; Singer, A.M. Nutritional Evaluation of Rumen Contents as a Slaughterhouse Waste in Sheep Rations. Egypt. J. Anim. Prod. 1996, 33, 173. 
119. Bhattacharya, A.N.; Taylor, J.C. Recycling Animal Waste as a Feedstuff: A Review. J. Anim. Sci. 1975, 41, 1438-1457. [CrossRef]

120. Sapkota, A.R.; Lefferts, L.Y.; Mckenzie, S.; Walker, P. What Do We Feed to Food-Production Animals? A Review of Animal Feed Ingredients and Their Potential Impacts on Human Health. Environ. Health Perspect. 2007, 115, 663-670. [CrossRef] [PubMed]

121. Onodera, T.; Kim, C.K. BSE Situation and Establishment of Food Safety Commission in Japan. J. Vet. Sci. 2006, 7, 1-11. [CrossRef] [PubMed]

122. Dormont, D. Prions, BSE and Food. Int. J. Food Microbiol. 2002, 78, 181-189. [CrossRef]

123. Doyle, M.E. Bovine Spongiform Encephalopathy: A Review of the Scientific Literature; Food Research Institute, University of Wisconsin: Madison, WI, USA, 2002.

124. Zafar, S.; Von Ahsen, N.; Oellerich, M.; Zerr, I.; Schulz-Schaeffer, W.J.; Armstrong, V.W.; Asif, A.R. Proteomics Approach to Identify the Interacting Partners of Cellular Prion Protein and Characterization of Rab7a Interaction in Neuronal Cells. J. Proteom. Res. 2011, 10, 3123-3135. [CrossRef] [PubMed]

125. Glatzel, M.; Aguzzi, A. Prpc Expression in the Peripheral Nervous System Is a Determinant of Prion Neuroinvasion. J. Gen. Virol. 2000, 81, 2813-2821. [CrossRef] [PubMed]

126. Kaatz, M.; Fast, C.; Ziegler, U.; Balkema-Buschmann, A.; Hammerschmidt, B.; Keller, M.; Oelschlegel, A.A.; Mcintyre, L.; Groschup, M.H. Spread of Classic BSE Prions from the Gut Via the Peripheral Nervous System to the Brain. Am. J. Pathol. 2012, 181, 515-524. [CrossRef] [PubMed]

127. Collinge, J. Prion Diseases of Humans and Animals: Their Causes and Molecular Basis. Ann. Rev. Neurosci. 2001, 24, 519-550. [CrossRef] [PubMed]

128. Hill, A.F.; Collinge, J. Subclinical Prion Infection in Humans and Animals. Br. Med. Bull. 2003, 66, 161-170. [CrossRef] [PubMed]

129. Houston, F.; Goldmann, W.; Chong, A.; Jeffrey, M.; González, L.; Foster, J.; Parnham, D.; Hunter, N. Prion Diseases: BSE in Sheep Bred for Resistance to Infection. Nature 2003, 423, 498. [CrossRef] [PubMed]

130. Collinge, J. Molecular Neurology of Prion Disease. J. Neurol. Neurosurg. Psychiatry 2005, 76, 906-919. [CrossRef] [PubMed]

131. Mathiason, C.K. Silent Prions and Covert Prion Transmission. Plospathog 2015, 11, 249. [CrossRef] [PubMed]

132. Momcilovic, D.; Rasooly, A. Detection and Analysis of Animal Materials in Food and Feed. J. Food Prot. 2000, 63, 1602-1609. [CrossRef] [PubMed]

133. United States Department of Health and Human Services. Substances Prohibited from Use in Animal Food or Feed; Final Rule. Fed. Regist. 2008, 73, 22720-22758.

134. Arduini, I.; Masoni, A.; Mariotti, M.; Ercoli, L. Low Cadmium Application Increase Miscanthus Growth and Cadmium Translocation. Environ. Exp. Bot. 2004, 52, 89-100. [CrossRef]

135. Mantovi, P.; Bonazzi, G.; Maestri, E.; Marmiroli, N. Accumulation of Copper and Zinc from Liquid Manure in Agricultural Soils and Crop Plants. Plant Soil 2003, 250, 249-257. [CrossRef]

136. Taggart, M.A.; Reglero, M.M.; Camarero, P.R.; Mateo, R. Should Legislation Regarding Maximum Pb and Cd Levels in Human Food Also Cover Large Game Meat? Environ. Int. 2011, 37, 18-25. [CrossRef] [PubMed]

137. Kim, M.; Schrenk, D. Chemical Contamination of Red Meat. In Chemical Contaminants and Residues in Food; Woodhead Publishing Series in Food Science, Technology and Nutrition; Woodhead Publishing: Cambridge, UK, 2012; pp. 447-468.

138. Nicholson, F.A.; Chambers, B.J.; Williams, J.R.; Unwin, R.J. Heavy Metal Contents of Livestock Feeds and Animal Manures in England and Wales. Bioresour. Technol. 1999, 70, 23-31. [CrossRef]

139. Loutfy, N.; Fuerhacker, M.; Tundo, P.; Raccanelli, S.; El Dien, A.G.; Ahmed, M.T. Dietary Intake of Dioxins and Dioxin-Like Pcbs, Due to the Consumption of Dairy Products, Fish/Seafood and Meat from Ismailia City, Egypt. Sci. Total Environ. 2006, 370, 1-8. [CrossRef] [PubMed]

140. Demirezen, D.; Uruç, K. Comparative Study of Trace Elements in Certain Fish, Meat and Meat Products. Meat Sci. 2006, 74, 255-260. [CrossRef] [PubMed]

(C) 2017 by the authors. Licensee MDPI, Basel, Switzerland. This article is an open access article distributed under the terms and conditions of the Creative Commons Attribution (CC BY) license (http://creativecommons.org/licenses/by/4.0/). 